3. Пометун О. І., Пироженко Л. В. Сучасний урок. Інтерактивні технології навчання: науково-методичний посібник / О. I. Пометун, Л. В. Пироженко; за ред. О. І. Пометун. Київ, 2004. 192 с.

4. Редько В. Інтерактивні технології навчання іноземної мови. Рідна школа. 2011. № 8-9. С. 28-36.

5. Шевченко Є. Використання інтерактивних технологій для розвитку пізнавального інтересу на уроках англійської мови. Англійська мова та література. 2005. № 24. С. 4-6.

DOI https://doi.org/10.30525/978-9934-26-180-0-54

\title{
ТЕСТОВИЙ КОНТРОЛЬ АУДИТИВНИХ УМІНЬ СТУДЕНТІВ НЕМОВНИХ СПЕЦІАЛЬНОСТЕЙ ЗВО У ПРОЦЕСІ ВИВЧЕННЯ ДИСЦИПЛІНИ «ІНОЗЕМНА МОВА (ЗА ПРОФЕСІЙНИМ СПРЯМУВАННЯМ»)
}

\author{
Черчата Л. М. \\ кандидат педагогічних наук, \\ доиент кафедри загального і слов'янського мовознавства \\ та іноземних мов \\ Полтавський національний педагогічний університет \\ імені В. Г. Короленка \\ м. Полтава, Украӥна
}

Аудіювання - це складний активний процес мовленнєвої діяльності, що потребує детального вивчення як 3 точки зору функціонування механізмів сприйняття, так і розвитку аудитивних умінь та навичок. Практичне володіння іноземною мовою, а надто англійською як мовою міжнародного спілкування $\epsilon$ викликом сьогодення. Цього потребує інтеграція України у міжнародний освітній простір із необмеженими можливостями навчатися в університетах закордоння й епоха сучасних технологій. Тому значення аудіювання як виду мовленнєвої діяльності посутньо зростає. Вміння розуміти сприйняте на слух усне мовлення набуває більшої значущості, оскільки воно сприяє формуванню низки компетенцій, як-от: міжкультурної, інформаційної чи то професійної. Тож актуальність навчання аудіювання постає незаперечною. До того ж його визнають одним із ефективних засобів розвитку комунікативних навичок, а сформована аудитивна компетенція $є$ важливим складником професійної 
діяльності майбутнього фахівця у будь-якій галузі. Зазначимо, що у пропонованому дослідженні аудитивна компетенція розуміється як здатність сприймати та розуміти іноземномовне мовлення на слух на основі набутих знань, вмінь та навичок. Зі слів М. Педі, аудіювання $\epsilon$ активним динамічним процесом концентрації уваги, сприйняття, інтерпретації, запам'ятовування та реакції на виражені вербально та невербально запити, проблеми та зовнішню інформацію [3]. М. Рост підкреслює фізіологічну природу цього процесу [5], а К. Адельман наголошує на тому, що слухання через призму іманентно діалогічної взаємодії між людьми $є$ одночасно сприйняттям та вираженням інформації [4]. Зважаючи на ці позиції, аудіювання можна концептуалізувати як активний усвідомлений мовленнєвий процес, основними етапами якого є сприйняття, розуміння і безпосередня інтерпретація звукової інформації, що надходить до учасника мовної комунікації. Для нашого дослідження важливо розглянути класифікацію рівнів розуміння тексту, розроблену О. Лурією. На переконання вченого, існує чотири рівні сприйняття та розуміння звукового повідомлення: рівень сприйняття та розуміння окремих слів; рівень сприйняття та розуміння окремих висловлювань; рівень сприйняття та розуміння цілого тексту; рівень сприйняття та розуміння внутрішнього змісту (підтексту) [2]. Кожен рівень відрізняється глибиною, повнотою і точністю розуміння тексту, що звучить, а також складністю розумових операцій, які здійснює слухач. Мінімальною одиницею аудіювання є слово, оскільки зі слова починається смислове сприйняття мови. При сприйнятті окремих звуків та звукосполучень має місце не аудіювання, а розпізнавання звукових сигналів. Процес сприйняття слова та розуміння його значення $є$ вибір значення слова з-поміж багатьох можливих варіантів, що зберігаються в довгостроковій пам'яті. Вибір варіанта здійснюється на основі аналізу співвідношення значення слова із загальним контекстом. Слухач здатний розрізняти на слух окремі слова і визначати тему повідомлення, що звучить, володіючи базовими навичками і вміннями аудіювання. Процес розуміння слів може ускладнюватися внаслідок омонімічності та багатозначність слова. Разом із цим частотність вживання слова слухачем і мовленнєвий контекст сприяють успішному сприйняттю і розумінню окремих слів у тексті, що звучить. Сприйняття і розуміння мовлення, що звучить, постає складною психічною i мовленнєвою діяльністю. Пропускна здатність звукового сигналу значно менше зорового, слухова пам'ять у більшості людей розвинена гірше за зорову пам'ять. Додаткові труднощі виникають у зв'язку з тим, що слухач перебуває у залежному становищі, так як не може вплинути на надходження звукової інформації. 
У реальному мовному спілкуванні звукова інформація учаснику комунікації пропонується одноразово. Потік звукової інформації надходить безперервно, тому слухачеві необхідно постійно утримувати увагу в полі звукового повідомлення, що надходить [2]. Будь-яка втрата концентрації уваги слухача призводить до паузи в прийомі інформації, і частина інформації, що надійшла в цей інтервал часу, ним не сприймається зовсім. У практичному курсі іноземної мови аудіювання є метою та засобом навчання. Будучи метою навчання, аудіювання забезпечує можливість розуміти на слух аудіотексти різного змісту та рівня складності, забезпечуючи тим самим досягнення практичної й виховної цілей навчання та формування вторинної мовної особистості. Як засіб навчання аудіювання у взаємодії з іншими видами мовленнєвої діяльності забезпечує формування знань, мовних навичок та умінь, підтримує та зберігає досягнутий рівень володіння мовою на всіх етапах навчання. Гоцинець I. акцентує увагу на тому, що основним завданням навчання аудіювання є стимулюваня у слухачів інтересу до змісту повідомлення, що сприятиме створенню необхідної комунікативної готовності до сприйняття інформації, в результаті чого з'являється антиципація - ймовірне прогнозування перебігу та змісту повідомлення. Саме антиципацію науковиця розглядає як ключовий фактор при сприйманні усного мовлення [1]. Як будь-який інший вид мовленнєвої діяльності, аудіювання є вмінням, тобто здатністю до розуміння іноземної мови на слух на основі формованих навичок та набутих знань, а тому його рівень можна виміряти 3 допомогою спеціальних форм контролю. Будь-якій формі контролю аудіювання має передувати повідомлення про те, яким чином перевірятиметься результат розуміння: чи мають вони після сприйняття тексту відповісти на запитання, виконати тест множинного вибору, скласти план до тексту або навести лад у запропонованій послідовності висловлювань, виписати ключові слова або вписати їх у запропоновану таблицю, класифікувавши їх відповідно до сприйнятої інформації. Палітра завдань для контролю розуміння дуже різноманітна. Основний критерій під час вибору того чи того контрольного завдання - мета роботи з аудіотекстом та зрозумілість використовуваного інструменту. Тест - це засіб контролю, що складається 3 кваліметрично вивіреної системи тестових завдань, стандартизованої процедури проведення та заздалегідь спроектованої технології оброблення та аналізу результатів, призначений для вимірювання обсягу сприйнятої в процесі слухання тексту інформації. Основна відмінність тесту від інших форм контролю полягає у тому, що він завжди передбачає вимірюваність, тому оцінка, що виставляється за підсумками тестування, вирізняється більшою об’єктивністю і незалежністю та передбачає 
мінімальне втручання викладача в процес оцінювання, а отже виключення елементу суб'єктивності оцінювання. Об'єктивність тестування досягається шляхом стандартизації процедури проведення, перевірки показників якості завдань і тестів у цілому. Тести уможливлюють варіювання складності матеріалу, що вимірюється, широти його охоплення, цільової спрямованості. Як відомо, тест складається з двох частин - інформаційної та операційної. Інформаційна частина містить зрозуміло й чітко сформульовану інструкцію та приклади правильного виконання тестових завдань. Операційна частина складається 3 певної кількості завдань чи питань. Тестове завдання містить основу (stem) у вигляді ствердного речення (повного чи неповного), питання чи невеликого тексту. Тестове завдання може супроводжуватися набором відповідей, які мають бути приблизно рівні за обсягом і належати до одного рівня мовної проблеми. Для перевірки сприйняття тексту на слух прийнято використовувати такі різновиди форматів тестів: множинний вибір (multiple choice); альтернативний вибір (True/False; Yes/No); підбір пар (matching); перенесення інформації (information transfer); перестановка у логічному порядку (ordering tasks); редагування (editing); заповнення пропусків (gap-filling); клоуз-тест (текст із пропущеними ключовими словами) (cloze); стислі відповіді. Система показників якості тесту дає можливість оцінити те, наскільки насправді створений інструмент відповідає цим вимогам, i використовувати його відповідно до цих вимог. Крім того, тести ефективні з економічної точки зору. Організацію тестового контролю адитивних умінь студентів немовних спеціальностей можна вважати успішно зреалізованою тільки за умови розроблення чи наявності придатного тесту, що потребує дотримання низки існуючих вимог 3 подальшим його пілотуванням. Отже, тестування визнано значним кроком на шляху розвитку методики контролю за засвоєнням студентами навчального матеріалу в силу можливості здійснення плавного переходу від суб'єктивного до максимально об'єктивного оцінювання. Своєю чергою, зазначимо, що тестовий контроль аудитивних умінь студентів немовних спеціальностей здатний забезпечити функціонування дієвого зворотного зв'язку в процесі навчання аудіювання, інакше кажучи, надає достовірну інформацію для управління й своєчасного коригування цього процесу.

\section{Література:}

1. Гоцинець І. Л. Методика формування аудитивних вмінь студентівфілологів на практичних заняттях 3 німецької мови. Молодий вчений. 2018.№ 3.1 (55.1). С. 31-35. 
2. Лурия А. Р. Язык и сознание; под. ред. Е. Д. Хомской. М. : Изд-во Моск. ун-та, 1979. 320 с.

3. Purdy M. What is listening? 1997. URL: https://www.researchgate.net/ publication/285272127_What_is_listening. (Last accessed: 17.03.2021).

4. Adelmann K. The Art of Listening in an Educational Perspective Listening reception in the mother tongue. URL: https://www.tandfonline.com/ doi/pdf/10.3402/edui.v3i4.22051. (Last accessed: 17.03.2021).

5. Rost M. Teaching and Researching Listening. Routledge, 2015. 342 p.

DOI https://doi.org/10.30525/978-9934-26-180-0-55

\title{
КОМУНІКАТИВНИЙ МЕТОД ВИВЧЕННЯ ІНОЗЕМНИХ МОВ
}

\author{
Шовкопляс О. I. \\ кандидат педагогічних наук, доиент, \\ доиент кафедри англійської мови \\ Державний університет телекомунікаиій \\ м. Київ, Украӥна
}

Сучасна методична наука $є$ комплексною наукою, що включає в себе лінгводидактику і методику навчання іноземним мовам. Лінгводидактика виступає в якості методологічного аспекту теорії навчання іноземної мови, та являється наукою, що вивчає і формує загальні закономірності способів засвоєння іншомовних знань, навичок і умінь [1, с. 252-254]. Методика навчання іноземної мови розглядає загальні положення, що стосуються процесу передачі іншомовних навичок, знань, умінь. Об'єктом методики виступає процес навчання іноземної мови або процес засвоєння студентами змісту освіти з іноземної мови в конкретних умовах навчання [2, с. 54].

На сьогоднішньому етапі більшість закладів вищої освіти застосовують підхід, заснований на компетентностях, де застосовуються активні та інтерактивні навчальні стратегії навчання [3, с. 61]. Перехід до освіти, заснованої на формуванні комунікативної компетентності студентів в межах вивчення іноземної мови, приносить користь як студентам, так і викладачам [4, с. 38]. Найважливішими завданнями в межах вивчення іноземної мови для формування комунікативної компетентності студентів $\epsilon$ наступні: накопичення, закріплення та відпрацювання словникового запасу, пов'язаного 3 професійним середовищем; формування навичок 